\title{
Knowledge of Zika and perception of risk among sexually-active adults in the United States of America: results from a nationally representative sample
}

\author{
Lucia Guerra-Reyes, ${ }^{1}$ Tsung-chieh Jane Fu, ${ }^{1}$ Deana Williams, ${ }^{2}$ \\ Debby Herbenick, ${ }^{1}$ Brian Dodge, ${ }^{1}$ Michael Reece, ${ }^{1}$ and \\ J. Dennis Fortenberry ${ }^{3}$
}

Suggested citation

Guerra-Reyes L, Fu TJ Williams D, Herbenick D, Dodge B, Reece M, et al. Knowledge of Zika and perception of risk among sexually-active adults in the United States of America: results from a nationally representative sample. Rev Panam Salud Publica. 2018;42:e43. https://doi.org/10.26633/RPSP.2018.43

ABSTRACT Objective. To examine knowledge of Zika transmission and risk perception and to assess variability by condom use in a probability sample of sexually-active adults in the United States. Methods. Data for this study came from the 2016 wave of the National Survey of Sexual Health and Behavior, a nationally representative probability sample of adults in the United States. Data were collected in November 2016 via a cross-sectional Internet-based survey administered to members of a Knowledge Panel, an address-based random sample service managed by GfK. A weighted subsample $(\mathrm{n}=1713)$ of sexually active adults, $18-50$ years of age, was included in analyses.

Results. More than 90\% of men and women reported low or no perceived risk of Zika. Most participants identified mosquito bite as a route of transmission, while significantly fewer identified sexual intercourse $(\approx 40 \%)$ and vertical $(29 \%$ men, $41 \%$ women) transmission routes.

Conclusion. Sexually-active adults in the United States, especially young men, lack awareness of sexual and vertical transmission of Zika Virus. Given the likely endemic nature of Zika, this low-risk perception is an important prevention challenge. Zika prevention messaging should address lesser known transmission routes, emphasize male education, and promote correct and consistent condom use.

Keywords Zika virus infection, prevention \& control; sexual health; United States.

Though the World Health Organization (WHO) no longer considers Zika Virus (ZIKV) a global health emergency (1), it remains a key concern for public health officials in affected countries, including the United States. However, research on

\footnotetext{
Center for Sexual Health Promotion, School of Public Health, Indiana University, Bloomington, Indiana, United States. Send correspondence to Lucia Guerra-Reyes, luguerra@ indiana.edu
}

knowledge of Zika, risk perception, and related sexual behaviors is scarce. This study analyzed data from a nationally-representative probability sample to examine knowledge about ZIKV transmission in the United States, as well as

\footnotetext{
Department of Applied Health Science, Indiana University, Bloomington, Indiana, United States.

Section of Adolescent Medicine, Indiana University School of Medicine, Bloomington, Indiana, United States.
}

risk perception; it also considered implications for long-term management of Zika in the United States.

ZIKV presents multiple forms of transmission: through the bite of an infected Aedes aegypti mosquito; through sexual intercourse; and from mother-to-child inutero $(2-6)$. ZIKV infection has been linked to increased cases of microcephaly and other types of cognitive impairment in infants $(7-9)$. It has also been linked 
to increased cases of Guillain-Barré syndrome, a condition that can lead to paralysis and death (10). In addition to the multiple forms of transmission, ZIKV presents a further challenge because only $20 \%$ of infected individuals demonstrate symptoms, limiting awareness of infection status and increasing risk of transmission (11). A Zika vaccine is in development, but there is currently no vaccine or cure for ZIKV infection (12).

ZIKV was deemed to be a "Public Health Emergency of International Concern" in February 2016 (1). This announcement was prompted by the rapid spread of ZIKV across Latin America and study results connecting it to a cluster of microcephaly cases in Brazil (13). In the United States, the Centers for Disease Control and Prevention (CDC) implemented enhanced surveillance systems, increased laboratory capacity to test for ZIKV, and focused prevention activities on pregnant women and vector control $(14-16)$.

On December 31st 2015, the first case of local ZIKV transmission was confirmed in the United States, in the territory of Puerto Rico (17). In January 2016, the CDC issued a travel warning advising pregnant women not to travel to areas with ongoing ZIKV transmission (18). By February 2016, one case of sexual transmission of Zika was reported in Texas. Then, in July 2016, four cases of locally-transmitted vector-borne Zika were confirmed in Miami, Florida (19). By December 2016, there were 5102 symptomatic cases of Zika reported in the continental United States, and 36079 cases reported in its territories, most of which were in Puerto Rico (20).

Existing CDC recommendations address both mosquito-borne and sexual forms of ZIKV transmission. Current recommendations state that pregnant women with sexual partners who live in or have traveled to an area with active ZIKV should consistently and correctly use condoms for vaginal, anal, and oral sex; or abstain from sex for the duration of pregnancy. Couples should consistently use reliable contraceptives or are advised to delay pregnancy. ZIKV testing is recommended for any individual with a possible exposure to the virus (21). The CDC also recognizes that access to contraception is essential to reducing ZIKV transmission $(18,22)$.

The unique characteristics of ZIKV, especially the multiple forms of transmission and large number of asymptomatic infections, challenge existing public health programs and require multi-level interventions for prevention and management. Increased knowledge of how sexual and reproductive behaviors intersect with ZIKV infection risk is important to design prevention efforts and messaging.

Scant scholarly publications have assessed Zika knowledge and perception of risk in the United States. Published articles to date have focused on identifying ecological level indicators of risk (23), assessing knowledge of Zika among construction workers (24), and understanding future Zika vaccine acceptance among college students (25). White paper reports and policy briefs based on national surveys and tracking polls have assessed knowledge of transmission, intention to delay pregnancy, and overall perception of risk (14, 26-28). However, there is little understanding of the intersection between ZIKV risk perception and sexual behaviors.

The present study sought to add to the emergent body of research on ZIKV in the United States. It presents results from Zika-related items on the 2016 wave of the National Survey of Sexual Health and Behavior, a nationally representative probability sample of adults in the United States. The objectives of the study were to assess what knowledge sexually-active men and women in the United States have on the ZIKV transmission mechanisms, how they perceive their risk of infection, and explore if these vary by condom-use levels.

\section{MATERIALS AND METHODS}

\section{Study population}

This was a cross-sectional analysis of data collected by the 2016 wave of the National Survey of Sexual Health and Behavior (NSSHB). It is a nationally representative probability survey of adults, and in some years, adolescents, that focuses on the sexual experiences of the United States population. Data were collected through the Knowledge Panel of GfK Research (Menlo Park, California, United States) during a 2-week period in November 2016. The GfK Knowledge Panel allows researchers to access nationally-representative probability samples and is frequently used for a variety of scientific studies, including those on health-related topics $(29-32)$.
Knowledge Panel members are recruited via address-based sampling, achieving approximately $98 \%$ coverage of all households in the United States. Selected households receive recruitment mailings and telephone calls; those consenting to participate complete a short demographic survey that allows for efficient panel sampling and weighting for future surveys. To minimize bias based on resources or Internet access, households without an Internet connection are provided with a web-enabled device and free Internet service upon enrollment into the research panel. Panel members completing the survey earn points that can be accumulated and exchanged for merchandise; no additional incentives were offered for participation.

Though the raw distribution of the Panel closely mirrors the United States population, an additional weighting process was applied to account for occasional disparities among subgroups due to differential attrition. Briefly, the active members of the Panel were weighted to the geodemographic benchmarks of the latest United States Census Bureau's "Current Population Survey" (CPS; 33). Using the resulting weights as measure of size, a probability proportional to size procedure was used to select the study sample for the 2016 NSSHB. Surveys were administered by GfK. Post-stratification weights, created with an iterative proportional fitting procedure to align to the benchmark distributions from the March 2016 CPS, were used to account for any differential non-response during the field period. All results in this study were generated using weighted data.

\section{Measures}

Measures were chosen based on review of published research and association with sexual transmission of ZIKV and other Sexually-transmitted Infections (STIs).

Basic demographics. Demographic data (e.g., age, gender, race/ethnicity, education, household income, geographic area) were collected by GfK during the panel recruitment process. Information on geographic area used the same categorization as the United States Census Bureau: Northeast, Midwest, South, and West (34).

For relationship status, participants were asked, "Which best describes your current relationship status?" Possible 
responses were: single and not dating, single and dating/hanging out with someone, in a relationship but not living together, living together but not married, married and living together, married but not living together. Sexual orientation data were collected by asking, "Do you consider yourself to be..." and possible responses were: heterosexual or straight, gay or lesbian, bisexual, asexual (not sexually attracted to other people), or something else.

Zika risk and transmission. The Zika measures used were adapted from items published by the WHO in its Knowledge, Attitudes, and Practices survey (35). To measure the perceived risk of Zika, participants were asked, "What is the risk that you will get Zika in the next 6 months?" Response options were: high risk, medium risk, low risk, or no risk. To assess the participants' knowledge of ZIKV transmission, they were asked, "How does a person get Zika?" Response options were: mosquito bite, from washing in polluted water, through sexual intercourse, through coughing and sneezing (i.e., airborne), from vaccinations, from mother-to-child transmission, and other. For this question, participants could select multiple answers.

Condom use. Participants were asked, "Of the last 10 times that you had penile-vaginal intercourse, how many of those times did you use a condom?" Response options ranged from every time ( 10 out of 10 times) to never ( 0 out of 10 times), with an additional option, "I have not done this 10 times." This condom-use item was re-categorized into three groups for analysis: "never" (0 out of 10 times), "sometimes" (1 - 9 out of 10 times), and "always" (10 out of 10 times).

\section{Data analysis}

Due to the focus on understanding perceived Zika risk among those at risk for sexual transmission, analyses was restricted to respondents who reported having had penile-vaginal intercourse in the 6 months prior to the survey. Participants' perceived risk of Zika in the next 6 months and responses on various modes of ZIKV transmission were presented descriptively, and stratified by gender and age; 95\% Confidence Intervals (95\%CI) for the percentages of each subgroup were calculated using adjusted Wald methods. Due to small sample sizes, in subsequent analyses those who perceived themselves as being at high risk of ZIKV infection were merged with those in the medium risk group.

Ordinal logistic regression was used to identify factors associated with different levels of perceived Zika risk. Potential variables assessed for perception of Zika risk included: gender (men/women); age (18 - 24 years / $25-50$ years); geographic area (Northeast / Midwest / South / West); relationship status (single / in a relationship / married); and condom use for the past 10 times of penile-vaginal intercourse (never / sometimes / always). Variables that were statistically significant in unadjusted models $(P<0.05)$ were further included in the adjusted ordinal logistic model. To summarize overall knowledge of ZIKV transmission, all the modes of transmission items were summed to create a knowledge score, with the incorrect modes of transmission reverse-coded. The final knowledge of transmission score could range from 0 (lowest knowledge level) to 7 (highest knowledge level). The three currently identified modes of transmission were mosquito bite, sexual intercourse, and mother-to-child transmission. Gamma regression with a log link was used to identify factors associated with knowledge of ZIKV transmission due to the skewness of the knowledge scores.

Potential variables assessed for ZIKV transmission knowledge included: gender (men/women), age (18 - 24 years / 25 - 50 years), race/ethnicity (White nonHispanic / Black non-Hispanic / Other non-Hispanic / Hispanic / Multiple race or ethnicities), education (less than high school / high school / some college / bachelor's degree or higher), annual household income in US\$ $(<25000 / 25000$ 49999 / 50000 - 74999 / 75000+), geographic area (Northeast / Midwest / South / West), and relationship status (single / in a relationship / married). Variables that were statistically significant in unadjusted models $(\mathrm{P}<0.05)$ were further included in the adjusted gamma regression model. All statistical analyses were conducted using Stata ${ }^{\circledR} /$ MP14 (StataCorp LP, College Station, Texas, United States).

\section{Ethics}

The Indiana University Institutional Review Board (Bloomington, Indiana,
United States) reviewed and approved all protocols associated with this study. No identifiable information was associated with the data, as it was anonymized by GfK before it reached the research team.

\section{RESULTS}

A total of 5070 adults $18-50$ years of age were invited to learn about a new survey available to them; the topic was not, however, disclosed at that time. Of those, 2594 (51\%) visited the website within the 2-week period allotted to learn more about the study and complete the initial screening. Of these, 2432 (94\%) consented to participate and completed the survey. Survey response rates for this study were higher than what is typical for online surveys (36).

\section{Social and demographic characteristics}

After excluding individuals who reported no penile-vaginal intercourse in the past 6 months, a weighted total of 1713 adults (807 men, 906 women) from $18-50$ years of age were included in the study analysis. Weighted sociodemographic characteristics of the sample are shown in Table 1.

The distributions of age, race/ethnicity, education, household income, and geographic area mirror the population of the United States at the time of the study (November 2016). Over 60\% of participants reported being married; slightly more men than women reported living with a partner (17\% vs. $14 \%)$; and more women than men reported being in a relationship, but not living together $(12 \%$ vs. $6 \%$ ). Most participants self-identified as heterosexual, though more women than men reported a sexual identity other than heterosexual ( $7 \%$ vs. $3 \%$ ).

\section{Knowledge of ZIKV transmission and perceived risk}

Participants' responses on their perceived risk of Zika in the next 6 months and various modes of ZIKV transmission are shown in Table 2, stratified by gender and age. Over $90 \%$ of both men and women either reported no risk or a low risk of Zika in the next 6 months, while approximately $3 \%$ reported a medium perceived risk and less than $1 \%$ reported a high perceived risk. Though slightly more men than women reported feeling 
TABLE 1. Weighted demographic characteristics by gender: National Survey of Sexual Health and Behavior, United States, 2016

\begin{tabular}{|c|c|c|c|c|c|c|}
\hline \multirow{2}{*}{ Characteristics } & \multicolumn{2}{|c|}{ Men $(n=807)$} & \multicolumn{2}{|c|}{ Women $(n=906)$} & \multicolumn{2}{|c|}{ Total $(n=1713)$} \\
\hline & $\%$ & $n$ & $\%$ & $n$ & $\%$ & $n$ \\
\hline \multicolumn{7}{|l|}{ Age in years } \\
\hline $18-24$ & 13.7 & 110 & 16.2 & 146 & 15.0 & 257 \\
\hline $25-39$ & 50.3 & 406 & 51.3 & 465 & 50.8 & 871 \\
\hline $40-50$ & 36.1 & 291 & 32.6 & 295 & 34.2 & 586 \\
\hline \multicolumn{7}{|l|}{ Race/ethnicity } \\
\hline White, non-Hispanic & 59.5 & 480 & 58.2 & 527 & 58.8 & 1007 \\
\hline Black, non-Hispanic & 11.1 & 90 & 12.1 & 109 & 11.6 & 199 \\
\hline Other, non-Hispanic & 6.8 & 55 & 8.9 & 81 & 7.9 & 136 \\
\hline Hispanic & 21.2 & 171 & 19.3 & 175 & 20.2 & 345 \\
\hline Multiple races/ethnicities & 1.4 & 11 & 1.6 & 14 & 1.5 & 25 \\
\hline \multicolumn{7}{|l|}{ Education } \\
\hline Less than high school & 10.6 & 85 & 9.2 & 84 & 9.9 & 169 \\
\hline High school & 26.9 & 217 & 22.8 & 206 & 24.7 & 423 \\
\hline Some college & 29.7 & 240 & 31.1 & 282 & 30.4 & 521 \\
\hline Bachelor's degree or higher & 32.9 & 265 & 36.9 & 334 & 35.0 & 600 \\
\hline \multicolumn{7}{|l|}{ Household income in US\$ } \\
\hline$<25000$ & 9.2 & 74 & 11.9 & 108 & 10.6 & 182 \\
\hline $25000-49999$ & 16.9 & 136 & 18.6 & 168 & 17.8 & 305 \\
\hline $50000-74999$ & 15.9 & 128 & 17.5 & 159 & 16.8 & 287 \\
\hline$\geq 75000$ & 58.1 & 469 & 52.0 & 471 & 54.9 & 940 \\
\hline \multicolumn{7}{|l|}{ Geographic area } \\
\hline Northeast & 17.2 & 139 & 15.6 & 141 & 16.3 & 280 \\
\hline Midwest & 22.0 & 178 & 21.0 & 190 & 21.5 & 368 \\
\hline South & 35.2 & 284 & 38.7 & 351 & 37.1 & 635 \\
\hline West & 25.5 & 206 & 24.8 & 224 & 25.1 & 430 \\
\hline \multicolumn{7}{|l|}{ Current relationship status ${ }^{\mathrm{a}}$} \\
\hline Single, not dating & 5.0 & 40 & 4.1 & 37 & 4.5 & 78 \\
\hline Single, dating someone & 8.9 & 72 & 6.6 & 60 & 7.7 & 132 \\
\hline In a relationship & 6.1 & 49 & 12.2 & 111 & 9.3 & 160 \\
\hline Living together & 17.1 & 138 & 13.5 & 122 & 15.2 & 260 \\
\hline Married, living together & 62.5 & 504 & 62.4 & 565 & 62.4 & 1070 \\
\hline Married, not living together & 0.4 & 3 & 1.2 & 11 & 0.8 & 14 \\
\hline \multicolumn{7}{|l|}{ Sexual orientation identity ${ }^{\mathrm{a}}$} \\
\hline Heterosexual & 97.3 & 785 & 93.3 & 846 & 95.2 & 1631 \\
\hline Homosexual & 0.2 & 1 & 0.2 & 2 & 0.2 & 3 \\
\hline Bisexual & 2.4 & 19 & 5.4 & 49 & 4.0 & 68 \\
\hline Asexual & 0.1 & 0 & 0.3 & 3 & 0.2 & 3 \\
\hline Other & 0.1 & 1 & 0.8 & 7 & 0.5 & 8 \\
\hline
\end{tabular}

${ }^{a} P$ value $<0.05$ based on chi-squared test for difference between genders.

Source: Prepared by the authors from the study results.

not at risk of Zika, and more women reported a low risk of Zika compared to men, the differences observed across gender and age groups were not statistically significant.

Regarding knowledge of ZIKV transmission, most men (91\%) and women (94\%) identified the mosquito bite transmission route, while significantly fewer identified sexual transmission (40\% men, $42 \%$ women) and mother-to-child transmission routes ( $29 \%$ men, $41 \%$ women). When analyzed by age group, findings showed that over $40 \%$ of participants
25 - 50 years of age knew that ZIKV could be transmitted through sexual intercourse. However, among those younger than 25 years of age, only 33\% of men and $31 \%$ of women identified a sexual transmission route. This difference across age groups was only statistically significant among women.

Gender differences in knowledge of vertical transmission of ZIKV were notable. Approximately $41 \%$ of women identified the mother-to-child ZIKV transmission route, compared with significantly fewer men (29\%). The percentage of participants who chose other incorrect ZIKV transmission routes was small, less than $10 \%$ across all gender and age groups. No statistically significant differences were identified across gender or age regarding all unidentified transmission routes of ZIKV.

Factors associated with perceived risk levels of Zika are presented in Table 3. In unadjusted models, women were found to be more likely to report increased levels of Zika risk perception in the next 6 months than men (Odds Ratio [OR] = 1.27; 95\%CI: $1.04-1.54)$. Likewise, participants from the Southern states were more likely to report higher perceived risk of Zika than those from the Northeast (OR = 1.63; 95\%CI: $1.12-2.37$ ). In addition, individuals who reported that they sometimes used condoms $(10 \%-90 \%$ of the time) among the past 10 times of penile-vaginal intercourse events were more likely to have a higher perceived risk of Zika than those who never used condoms $(\mathrm{OR}=1.72$; 95\%CI: $1.19-2.50)$.

In the final adjusted model, after controlling for geographic area and condom use, we no longer observed a statistically significant association between gender and perceived Zika risk. However, living in Southern states was still associated with a greater likelihood of reporting a higher level of perceived Zika risk than living in Northeastern states (adjusted OR [adjOR] = 1.75; 95\%CI: 1.15 - 2.66). Similarly, participants who sometimes used condoms (the last 10 times they had penile-vaginal intercourse) were statistically significantly more likely to report higher levels of perceived Zika risk (adjOR = 1.83; 95\%CI: $1.26-2.65$ ). No differences were observed between participants who always used condoms and those who never used condoms.

\section{Factors associated with knowledge of ZIKV transmission}

Factors associated with knowledge of ZIKV transmission routes-calculated as a knowledge score-are presented in Table 4. In unadjusted models, participants who are women, 25 - 50 years of age, educated with some college or more, and in a relationship or married, demonstrated a significantly higher knowledge of ZIKV transmission. Being Black nonHispanic was associated with a lower knowledge score of ZIKV transmission than being White. 
TABLE 2. Perceived risk of Zika infection in the next 6 months and modes of transmission: National Survey of Sexual Health and Behavior, United States, 2016

\begin{tabular}{|c|c|c|c|c|c|c|c|c|c|c|c|c|}
\hline \multirow{3}{*}{ Characteristics } & \multicolumn{6}{|c|}{ Men } & \multicolumn{6}{|c|}{ Women } \\
\hline & \multicolumn{2}{|r|}{ Total } & \multicolumn{2}{|c|}{$18-24$ years of age } & \multicolumn{2}{|c|}{$25-50$ years of age } & \multicolumn{2}{|r|}{ Total } & \multicolumn{2}{|c|}{$18-24$ years of age } & \multicolumn{2}{|c|}{$25-50$ years of age } \\
\hline & $n$ & $\%(95 \% \mathrm{Cl})$ & $n$ & $\%(95 \% \mathrm{Cl})$ & $n$ & $\%(95 \% \mathrm{Cl})$ & $n$ & $\%(95 \% \mathrm{Cl})$ & $n$ & $\%(95 \% \mathrm{Cl})$ & $n$ & $\%(95 \% \mathrm{Cl})$ \\
\hline \multicolumn{13}{|l|}{ Risk of Zika in the next 6 months } \\
\hline No risk & 517 & $\begin{array}{c}64.6 \\
(60.2,68.8)\end{array}$ & 70 & $\begin{array}{c}63.6 \\
(44.5,79.2)\end{array}$ & 447 & $\begin{array}{c}64.8 \\
(60.3,69.0)\end{array}$ & 528 & $\begin{array}{c}58.7 \\
(54.5,62.7)\end{array}$ & 97 & $\begin{array}{c}67.5 \\
(52.6,79.6)\end{array}$ & 431 & $\begin{array}{c}57.0 \\
(52.8,61.1)\end{array}$ \\
\hline Low risk & 253 & $\begin{array}{c}31.6 \\
(28.0,35.3)\end{array}$ & 30 & $\begin{array}{c}27.4 \\
(15.7,43.2)\end{array}$ & 223 & $\begin{array}{c}32.2 \\
(28.4,36.3)\end{array}$ & 338 & $\begin{array}{c}37.6 \\
(33.4,41.9)\end{array}$ & 40 & $\begin{array}{c}27.9 \\
(15.9,44.0)\end{array}$ & 298 & $\begin{array}{c}39.4 \\
(35.5,43.5)\end{array}$ \\
\hline High risk & 5 & $\begin{array}{c}0.6 \\
(0.1,2.5)\end{array}$ & 0 & $\begin{array}{c}0.3 \\
(0.0,2.4)\end{array}$ & 4 & $\begin{array}{c}0.6 \\
(0.1,3.0)\end{array}$ & 4 & $\begin{array}{c}0.4 \\
(0.1,1.2)\end{array}$ & 0 & $\begin{array}{l}0.0 \\
(-)\end{array}$ & 4 & $\begin{array}{c}0.5 \\
(0.1,1.4)\end{array}$ \\
\hline \multicolumn{13}{|l|}{ Zika modes of transmission } \\
\hline Mosquito bite & 717 & $\begin{array}{c}90.9 \\
(88.2,93.0)\end{array}$ & 91 & $\begin{array}{c}86.7 \\
(74.0,93.7)\end{array}$ & 626 & $\begin{array}{c}91.5 \\
(88.5,93.8)\end{array}$ & 834 & $\begin{array}{c}93.7 \\
(92.2,95.0)\end{array}$ & 127 & $\begin{array}{c}91.5 \\
(82.1,96.2)\end{array}$ & 706 & $\begin{array}{c}94.1 \\
(92.1,95.7)\end{array}$ \\
\hline Through coughing and sneezing & 54 & $\begin{array}{c}6.8 \\
(4.8,9.6)\end{array}$ & 8 & $\begin{array}{c}7.4 \\
(3.5,14.7)\end{array}$ & 46 & $\begin{array}{c}6.7 \\
(4.6,9.7)\end{array}$ & 49 & $\begin{array}{c}5.5 \\
(3.9,7.8)\end{array}$ & 6 & $\begin{array}{c}4.4 \\
(1.7,10.9)\end{array}$ & 43 & $\begin{array}{c}5.7 \\
(4.0,8.2)\end{array}$ \\
\hline From washing in polluted water & 41 & $\begin{array}{c}5.2 \\
(3.7,7.3)\end{array}$ & 7 & $\begin{array}{c}6.3 \\
(3.5,10.9)\end{array}$ & 35 & $\begin{array}{c}5.1 \\
(3.4,7.5)\end{array}$ & 43 & $\begin{array}{c}4.8 \\
(3.5,6.6)\end{array}$ & 10 & $\begin{array}{c}7.1 \\
(2.8,16.7)\end{array}$ & 33 & $\begin{array}{c}4.4 \\
(3.1,6.2)\end{array}$ \\
\hline From vaccinations & 14 & $\begin{array}{c}1.8 \\
(0.9,3.6)\end{array}$ & 1 & $\begin{array}{c}1.3 \\
(0.3,5.9)\end{array}$ & 13 & $\begin{array}{c}1.9 \\
(0.8,4.0)\end{array}$ & 4 & $\begin{array}{c}0.5 \\
(0.2,1.3)\end{array}$ & 0 & $\begin{array}{l}0.0 \\
(-)\end{array}$ & 4 & $\begin{array}{c}0.5 \\
(0.2,1.5)\end{array}$ \\
\hline Other & 40 & $\begin{array}{c}5.1 \\
(3.1,8.2)\end{array}$ & 9 & $\begin{array}{c}8.4 \\
(2.4,25.7)\end{array}$ & 31 & $\begin{array}{c}4.6 \\
(2.7,7.5)\end{array}$ & 29 & $\begin{array}{c}3.3 \\
(2.1,5.1)\end{array}$ & 8 & $\begin{array}{c}5.4 \\
(1.6,16.7)\end{array}$ & 22 & $\begin{array}{c}2.9 \\
(1.7,4.9)\end{array}$ \\
\hline
\end{tabular}

Source: Prepared by the authors from the study results.

TABLE 3. Factors associated with perceived risk of Zika infection ${ }^{a}$ in the next 6 months using ordinal logistic regression: National Survey of Sexual Health and Behavior, United States, 2016

\begin{tabular}{|c|c|c|c|c|}
\hline \multirow{2}{*}{ Variables } & \multicolumn{2}{|c|}{ Unadjusted models } & \multicolumn{2}{|c|}{ Adjusted model ${ }^{b}$} \\
\hline & Odds Ratio & $95 \% \mathrm{Cl}$ & Adjusted OR & $95 \% \mathrm{Cl}$ \\
\hline \multicolumn{5}{|l|}{ Gender } \\
\hline Men & 1.00 & - & 1.00 & - \\
\hline Women & 1.27 & $1.04,1.54^{c}$ & 1.18 & $0.95,1.46$ \\
\hline \multicolumn{5}{|l|}{ Age in years } \\
\hline $18-24$ & 1.00 & - & - & - \\
\hline $25-39$ & 1.11 & $0.71,1.75$ & - & - \\
\hline $40-50$ & 1.29 & $0.70,2.37$ & - & - \\
\hline \multicolumn{5}{|l|}{ Geographic area } \\
\hline Northeast & 1.00 & - & 1.00 & - \\
\hline Midwest & 0.97 & $0.64,1.47$ & 0.78 & $0.51,1.21$ \\
\hline South & 1.63 & $1.12,2.37^{c}$ & 1.75 & $1.15,2.66^{c}$ \\
\hline West & 1.39 & $0.97,2.00$ & 1.51 & $0.97,2.34$ \\
\hline \multicolumn{5}{|l|}{ Relationship status } \\
\hline Single & 1.00 & - & - & - \\
\hline In a relationship & 0.96 & $0.51,1.80$ & - & - \\
\hline Married & 0.99 & $0.56,1.76$ & - & - \\
\hline \multicolumn{5}{|c|}{ Condom use in past 10 times of penile-vaginal intercourse } \\
\hline Never & 1.00 & - & 1.00 & - \\
\hline Sometimes & 1.72 & $1.19,2.50^{c}$ & 1.83 & $1.26,2.65^{c}$ \\
\hline Always & 1.01 & $0.69,1.48$ & 1.04 & $0.71,1.53$ \\
\hline
\end{tabular}

Some associations of knowledge of ZIKV transmission with household income were observed, though no consistent trend was found across the different categories. Findings showed that respondents in households with annual incomes of US\$ 25000 - US\$ 49999 and $\geq$ US\$ 75000 were significantly more likely to have higher knowledge of ZIKV transmission than those with households incomes < US\$ 25000. Interestingly, there were no observable differences regarding knowledge of ZIKV transmission by geographic area, even though a difference in perceived risk was previously observed.

In the adjusted model, after controlling for gender, education, household income, and relationship status, the associations between age, race/ethnicity, and knowledge of ZIKV transmission were no longer observed. Women's scores regarding ZIKV transmission routes were significantly higher than those of men $(\beta=0.04 ; \mathrm{SE}=0.01 ; P=$ 0.004). Likewise, those of individuals with some college education $(\beta=0.07$; $\mathrm{SE}=0.03 ; P=0.009)$ or a Bachelor's degree or more $(\beta=0.11 ; \mathrm{SE}=0.03 ; P=0.00)$ were higher than those with incomplete high school. 
TABLE 4. Factors associated with knowledge of Zika virus transmission using gamma regression: National Survey of Sexual Health and Behavior, United States, 2016

\begin{tabular}{|c|c|c|c|c|c|c|c|}
\hline \multirow{2}{*}{ Variables } & \multirow{2}{*}{$\begin{array}{c}\begin{array}{c}\text { Zika transmission } \\
\text { knowledge score }\end{array} \\
\text { Mean (SD) }\end{array}$} & \multicolumn{3}{|c|}{ Unadjusted models } & \multicolumn{3}{|c|}{ Adjusted model } \\
\hline & & $\beta$ & SE & $P$-value & $\beta$ & SE & $P$-value \\
\hline \multicolumn{8}{|l|}{ Gender } \\
\hline Men & $5.41(1.01)$ & 0.00 & - & - & 0.00 & - & - \\
\hline Women & $5.62(0.99)$ & 0.04 & 0.01 & 0.005 & 0.04 & 0.01 & 0.004 \\
\hline \multicolumn{8}{|l|}{ Age in years } \\
\hline $18-24$ & $5.34(0.85)$ & 0.00 & - & - & 0.00 & - & - \\
\hline $25-39$ & $5.54(1.13)$ & 0.04 & 0.02 & 0.022 & 0.01 & 0.02 & 0.655 \\
\hline $40-50$ & $5.58(0.86)$ & 0.04 & 0.02 & 0.023 & 0.01 & 0.02 & 0.393 \\
\hline \multicolumn{8}{|l|}{ Race/ethnicity } \\
\hline White, non-Hispanic & $5.57(1.09)$ & 0.00 & - & - & 0.0 & - & - \\
\hline Black, non-Hispanic & $5.22(0.90)$ & -0.06 & 0.02 & 0.008 & -0.04 & 0.02 & 0.063 \\
\hline Other, non-Hispanic & $5.53(0.72)$ & -0.01 & 0.02 & 0.702 & -0.02 & 0.01 & 0.096 \\
\hline Hispanic & $5.55(0.84)$ & 0.00 & 0.02 & 0.870 & 0.02 & 0.02 & 0.118 \\
\hline Multiple races/ethnicities & $5.64(1.31)$ & 0.01 & 0.03 & 0.663 & 0.03 & 0.02 & 0.198 \\
\hline \multicolumn{8}{|l|}{ Education } \\
\hline Less than high school & $5.08(0.67)$ & 0.00 & - & - & 0.00 & - & - \\
\hline High school & $5.35(0.94)$ & 0.05 & 0.03 & 0.112 & 0.04 & 0.03 & 0.167 \\
\hline Some college & $5.51(1.03)$ & 0.08 & 0.03 & 0.004 & 0.07 & 0.03 & 0.010 \\
\hline Bachelor's degree or higher & $5.78(1.04)$ & 0.13 & 0.03 & $<0.001$ & 0.11 & 0.03 & 0.001 \\
\hline \multicolumn{8}{|l|}{ Household income in US\$ } \\
\hline$<25000$ & $5.08(1.20)$ & 0.00 & - & - & 0.00 & - & - \\
\hline $25000-49999$ & $5.55(1.01)$ & 0.09 & 0.02 & $<0.001$ & 0.06 & 0.02 & 0.002 \\
\hline $50000-74999$ & $5.33(1.12)$ & 0.05 & 0.02 & 0.038 & 0.00 & 0.02 & 0.951 \\
\hline$\geq 75000$ & $5.66(0.90)$ & 0.11 & 0.02 & $<0.001$ & 0.04 & 0.02 & 0.023 \\
\hline \multicolumn{8}{|l|}{ Geographic area } \\
\hline Northeast & $5.50(1.08)$ & 0.00 & - & - & - & - & - \\
\hline Midwest & $5.49(1.09)$ & 0.00 & 0.01 & 0.880 & - & - & - \\
\hline South & $5.51(0.90)$ & 0.00 & 0.01 & 0.908 & - & - & - \\
\hline West & $5.58(1.05)$ & 0.01 & 0.01 & 0.209 & - & - & - \\
\hline \multicolumn{8}{|l|}{ Relationship status } \\
\hline Single & $5.17(1.11)$ & 0.00 & - & - & 0.00 & - & - \\
\hline In a relationship & $5.37(0.98)$ & 0.04 & 0.02 & 0.041 & 0.02 & 0.02 & 0.213 \\
\hline Married & $5.65(0.97)$ & 0.09 & 0.02 & $<0.001$ & 0.05 & 0.02 & 0.005 \\
\hline
\end{tabular}

Source: Prepared by the authors from the study results.

After adjusting for other factors, being married was significantly associated with higher knowledge scores of ZIKV transmission than being single $(\beta=0.05 ; \mathrm{SE}=$ 0.02; $P=0.004)$. Household income still appeared to be associated with knowledge of ZIKV transmission, though no consistent trend was observed, and the effect was attenuated after adjusting for other factors.

Differences in knowledge score between bisexual and heterosexual participants were not significant.

\section{DISCUSSION}

Prior research from nationally representative data $(14,26)$, in addition to polling data $(27,28)$, indicates that adults in the United States are aware of ZIKV.
However, the research also indicates that awareness does not translate to knowledge. One study found (14) that while awareness was around $85 \%$, correct knowledge of main ZIKV characteristics (sexual and mosquito transmission, asymptomatic cases, and neural defects) only amounted to around $34 \%$ of adults. Another study (26) indicated that while women of reproductive age had overwhelmingly heard about Zika (76.2\%), only 33\% felt they were at risk.

Our results on sexually-active adults in the United States similarly show low levels of perceived risk of Zika infection (less than $10 \%$ ). When stratified geographically, we observed a slightly larger perceived risk in the country's southern states. This corresponds closely to the areas identified as high risk by Shacham and colleagues (23). The elevated perception of risk is not surprising given that the southern states of Florida and Texas have higher case prevalence to date (37) and received intense media messaging and public health interventions.

The perceived low risk of ZIKV infection among those who never used condoms during sexual intercourse, even in higher risk areas, highlights the dearth of information on sexual transmission of the virus among sexually-active adults in the United States. Furthermore, our results demonstrate that knowledge of ZIKV transmission routes is incomplete among adults potentially at risk, especially those $18-25$ years of age. While mosquito transmission is widely recognized, sexual and mother-to-child transmission are not. This gap in knowledge of ZIKV transmission is highly problematic when considering the already existing low levels of risk perception, the high prevalence of asymptomatic Zika cases, and relatively inconsistent condom use.

Knowledge of non-mosquito forms of transmission is considerably lower among men. Similar to other reproductive and sexual health programs (38), most of the messaging and outreach regarding Zika prevention has targeted women of reproductive age and pregnant women. This obscures the role of men in reproductive decision-making (39), and also limits their ability to become active partners in Zika prevention and management. Our results demonstrate that it is crucially important to involve men in Zika responses.

Similar to an earlier study (14), knowledge of ZIKV transmission was higher among married and more highly educated participants. These results suggest that information about Zika is not reaching those who might be more vulnerable in terms of health care access, i.e., single and less educated adults who are more likely to suffer from health inequalities $(40,41)$.

Limitations. While our results provide important and new information on the state of Zika risk perception and transmission knowledge among at-risk adults in the United States, this study has several limitations. We could only provide data for the continental United States, and not for its territories that have higher Zika prevalence. We also could not provide data on other Zika specific questions, such as the knowledge about 
widespread asymptomatic cases; likelihood of changing condom use behaviors with more information; or changes in pregnancy intention. Due to the grave health impacts of Zika on infants, we focused our analyses on individuals reporting penile-vaginal intercourse, although subsequent research might also examine condom use behaviors during oral and anal sex. Furthermore, although we had information on the participants' place of residence, we did not ask about recent or upcoming travel plans to areas of known Zika risk. Such information would have added context to real or perceived risk. Lastly, the language of the survey limited participation by those who do not read English.

\section{Conclusions}

Sexually-active adults in the United States, especially younger men, have limited knowledge of non-mosquito-borne forms of ZIKV transmission and low perception of their risk of infection. Condom use was not significantly associated with risk perception or transmission knowledge, and overall, was inconsistent in the sample.

Long-term Zika prevention and management faces several challenges as a result of the multiple forms of ZIKV transmission. The most prevalent form, mosquito-borne transmission, has been the focus of the majority of messaging and public health actions. Our results suggest that it is necessary to increase public knowledge of sexual and vertical transmission of the virus.

Creation of programs and messaging specifically targeting men, and more importantly young men, are needed for Zika prevention. Given that the main prevention of sexual transmission is the male condom, it is important that messages emphasize the importance of correct and consistent condom use, even in the absence of symptoms. A way to accomplish this would be to fold ZIKV information into broader STI prevention efforts, engaging men as peer educators in the same way innovative HIV interventions have done $(42,43)$. The new endemic nature of Zika will require full integration of preventive messages on sexually transmitted infections to vulnerable populations, improving access to condoms, and promoting their use.

Funding. This study was funded by Church and Dwight Incorporated (Cincinnati, Ohio, United States), maker of Trojan $^{\circledR}$ condoms.

\section{Conflict of interests: None declared.}

Disclaimer. Authors hold sole responsibility for the views expressed in the manuscript, which may not necessarily reflect the opinion or policy of the RPSP/ PAJPH and/or PAHO.

\section{REFERENCES}

1. World Health Organization. WHO Statement. Fifth meeting of the emergency committee under the International Health Regulations (2005) regarding microcephaly, other neurological disorders and Zika virus. Geneva: WHO; 2016. Available from: www.who.int/mediacentre/news/ statements/2016/zika-fifth-ec/en/ Accessed 18 January 2018.

2. Hajra A, Bandyopadhyay D, Hajra SK. Zika Virus: a global threat to humanity. A comprehensive review and current developments. N Am J Med Sci. 2016;8(3):123-8.

3. D'Ortenzio E, Matheron S, de Lamballerie X, Hubert B, Piorkowski G, Maquart M, et al. Evidence of sexual transmission of Zika Virus. N Engl J Med. Available from: http://dx.doi.org/10.1056/NEJMc 1604449 Accessed 27 April 2016.

4. Paixão ES, Barreto F, da Glória Teixeira M, da Conceição N. Costa M, Rodrigues LC. History, epidemiology, and clinical manifestations of Zika: a systematic review. Am J Public Health. 2016;106(4):606-12.

5. Petersen LR, Jamieson DJ, Powers AM, Honein MA. Zika Virus. N Engl J Med. 2016;374(16):1552-63.

6. Rodriguez-Morales AJ, Bandeira AC, Franco-Paredes $\mathrm{C}$. The expanding spectrum of modes of transmission of Zika virus: a global concern. Ann Clin Microbiol Antimicrob. 2016;15.

7. Torjesen I. Zika virus outbreaks prompt warnings to pregnant women. BMJ. 2016; 352:i500. Available from: https://doi.org/ 10.1136/bmj.i500 Accessed 18 January 2018.

8. Calvet G, Aguiar RS, Melo ASO, Sampaio SA, de Filippis I, Fabri A, et al. Detection and sequencing of Zika virus from amniotic fluid of fetuses with microcephaly in Brazil: a case study. Lancet Infect Dis. 2016;S1473-3099(16):00095-5.

9. Rodriguez-Morales AJ. Zika and microcephaly in Latin America: An emerging threat for pregnant travelers? Travel Med Infect Dis. 2016;14(1):5-6.

10. Wise J. Study links Zika virus to GuillainBarre syndrome. BMJ. 2016;352:i1242. Available from: https://doi.org/10.1136/ bmj.i1242 Accessed 18 January 2018.

11. Duffy MR, Chen T-H, Hancock WT, Powers AM, Kool JL, Lanciotti RS, et al. Zika virus outbreak on Yap Island, federated states of Micronesia. N Engl J Med. 2009;360(24):2536-43.

12. World Health Organization. Zika virus factsheet 2016. Geneva: WHO; 2016. Available from: www.who.int/mediacentre/factsheets/zika/en/ Accessed 18 January 2018.

13. Lucey DR, Gostin LO. The emerging Zika pandemic: enhancing preparedness. JAMA. 2016;315(9):865-6.

14. Abramson D, Pitch-Loeb R. U.S. public's perception of Zika risk: awareness, knowledge, and receptivity to public health interventions. New York: New York University; 2016. Pp. 1-23.

15. Boulet SL. Contraceptive use among nonpregnant and postpartum women at risk for unintended pregnancy, and female high school students, in context of Zika prepardness-United States, 2011-2013 and 2015. MMWR. 2016;65(30):780-7.

16. Dirlikov E. Update: ongoing Zika Virus transmission-Puerto Rico, 1 November 2015 - 12 April 2016. MMWR. 2016;65(17): $451-5$.
17. World Health Organization. Zika virus infection, United States of America-Puerto Rico, 2016. Geneva: WHO; 2016. Available from: https:/ / www.cdc.gov/zika/reporting/2016-case-counts.html Accessed on 18 January 2018.

18. Oussayef NL. Zika Virus: 10 public health achievements in 2016 and future priorities. MMWR. 2016;65(52):1482-8.

19. Likos A, Griffin I, Bingham AM, Stanek D, Fischer M, White S, et al. Local mosquito-borne transmission of Zika Virus, Miami-Dade and Broward Counties, Florida, June-August 2016. MMWR. 2016; 65:1032-8.

20. United States Centers for Disease Control and Prevention. ZIKA CDC 2016 Case Counts. Available from: https://www. cdc.gov/zika/reporting/2016-casecounts.html Accessed 28 September 2017.

21. Brooks JT. Update: interim guidance for prevention of sexual transmission of Zika. MMWR. 2016;65(29):745-7.

22. Tepper NK. Estimating contraceptive needs and increasing access to contraception in response to the Zika Virus disease outbreak, Puerto Rico, 2016. MMWR. 2016;65(12):311-4.

23. Shacham E, Nelson EJ, Hoft DF, Schootman M, Garza A. Potential high-risk areas for Zika Virus transmission in the contiguous United States. Am J Public Health. 2017;107(5):724-31.

24. Moore KJ, Qualls W, Brennan V, Yang X, Caban-Martinez AJ. Mosquito control practices and Zika knowledge among outdoor construction workers in Miami-Dade County, Florida. J Occup Environ Med. 2017;59(3):e17-e9. 
25. Painter JE, Plaster AN, Tjersland DH, Jacobsen KH. Zika virus knowledge, attitudes, and vaccine interest among university students. Vaccine. 2017;35(6):960-5.

26. Shartzer A, Johnston E, Courtot B, Kenney GM. Women of reproductive age lack knowledge of Zika Virus transmission and effects. Washington DC: Urban Institute Health Policy Center; 2016.

27. March of Dimes Foundation, National Opinion Research Center Chicago. The Zika Virus: gaps in Americans' knowledge and support for government action. Available from: www.norc.org/PDFs/ MarchOfDimes / Report_March_of Dimes_NORC_Zika_Poll_090616.pdf Accessed 18 January 2018.

28. Kaiser Family Foundation. Survey of Americans on the U.S. role in global health and Kaiser Family Foundation Health Tracking Polls. Available from: https:// www.kff.org/global-health-policy / pollfinding/2016-survey-of-americans-onthe-u-s-role-in-global-health/ Accessed 18 January 2018.

29. Chang L, Krosnick JA. National surveys via RDD telephone interviewing versus the Internet: comparing sample representativeness and response quality. Public Opin Q. 2009;73(4):641-78.

30. Harris KM, Schonlau M, Lurie N. Surveying a nationally representative internet-based panel to obtain timely estimates of influenza vaccination rates. Vaccine. 2009;27(6):815-8.

31. Herbenick D, Reece M, Schick V, Sanders SA, Dodge B, Fortenberry JD. An event- level analysis of the sexual characteristics and composition among adults ages 18 to 59: results from a national probability sample in the United States. J Sex Med. 2010;7(s5):346-61.

32. Rothman EF, Edwards EM, Heeren T, Hingson RW. Adverse childhood experiences predict earlier age of drinking onset: results from a representative US sample of current or former drinkers. Pediatrics. 2008;122(2):e298-e304.

33. United States Census Bureau and Bureau of Labor Statistics. Current Population Survey. Available from: https: / /www.census.gov/programs-surveys/cps.html Accessed 18 January 2018.

34. United States Census Bureau. Geographic terms and concepts-census divisions and census regions 2015. Available from: https: / / www.census.gov/geo/reference/gtc/gtc_census_divreg.html Accessed 18 January 2018.

35. World Health Organization. Knowledge, attitudes and practice surveys. Zika virus disease and potential complications. Resource Pack 2016. Geneva: WHO; 2016. Available from: www.who.int/csr/resources/publications/zika/kap-surveys / en/ Accessed 18 January 2018.

36. Sauermann H, Roach M. Increasing web survey response rates in innovation research: An experimental study of static and dynamic contact design features. Research Policy. 2013;42(1):273-86.

37. United States Centers for Disease Control and Prevention. Zika cases in the United States, 2017. Available from: https:// www.cdc.gov / zika / reporting / casecounts.html Accessed 18 January 2018.

38. Osamor PE, Grady C. Zika Virus: promoting male involvement in the health of women and families. PLoS Negl Trop Dis. 2016;10(12):e0005127.

39. Gutmann M. Fixing men: sex, birth control, and AIDS in Mexico. Oakland: University of California Press; 2007.

40. Marmot M. Social determinants of health inequalities. Lancet. 2005;365 (9464):1099-104.

41. Adler NE, Newman K. Socioeconomic disparities in health: pathways and policies. Health Aff. 2002;21(2):60-76.

42. Rhodes SD, Daniel J, Alonzo J, Vissman AT, Duck S, Downs M, et al. A snapshot of how Latino heterosexual men promote sexual health within their social networks: Process evaluation findings from an efficacious community-level intervention. AIDS Educ Prev. 2012;24(6):514-26.

43. Wilson TE, Fraser-White M, Williams KM, Pinto A, Agbetor F, Camilien B, et al. Barbershop talk with brothers: using community-based participatory research to develop and pilot test a program to reduce HIV risk among Black heterosexual men. AIDS Educ Prev. 2014;26(5):383-97.

Manuscript received on 3 August 2017. Accepted for publication on 12 October 2017.
RESUMEN

\section{Conocimiento sobre el virus del Zika y percepción del riesgo en adultos sexualmente activos en los Estados Unidos de América: resultados de una muestra representativa a nivel nacional}

Palabras clave
Objetivo. Examinar el conocimiento y la percepción del riesgo en cuanto a la transmisión del virus del Zika y evaluar la variabilidad en el uso de preservativos en una muestra probabilística de adultos sexualmente activos en los Estados Unidos.

Métodos. Los datos usados en este estudio se tomaron de las respuestas que una muestra probabilística representativa a nivel nacional de adultos de los Estados Unidos dio en el 2016 como parte de la Encuesta nacional sobre salud y comportamiento sexual. La recopilación de datos se hizo en noviembre del 2016 mediante un cuestionario transversal en línea que respondieron los miembros de Knowledge Panel, un servicio de muestras aleatorias seleccionadas por la dirección de los usuarios que presta la empresa GfK. Para los análisis se usó una submuestra ponderada $(n=1713)$ de adultos sexualmente activos de 18 a 50 años de edad.

Resultados. Más de $90 \%$ de los hombres y mujeres encuestados informaron que su nivel de percepción sobre el riesgo del virus del Zika era bajo o nulo. La mayoría de los participantes sabía que la picadura de mosquitos es una vía de contagio, y un número significativamente menor de participantes sabía que el virus puede transmitirse por relaciones sexuales $(\approx 40 \%)$ y de madre a hijo $(29 \%$ de los hombres, $41 \%$ de las mujeres).

Conclusiones. Los adultos sexualmente activos en los Estados Unidos - y en particular, los hombres jóvenes - tienen escaso conocimiento acerca de la transmisión sexual y vertical del virus del Zika. Dada la probable naturaleza endémica de este virus, esta percepción de que el riesgo es bajo constituye un reto importante para las iniciativas de prevención. Los mensajes sobre la prevención de la infección por el virus del Zika deben abordar las rutas de transmisión menos conocidas, hacer hincapié en educar a los hombres, y promover el uso correcto y sistemático de preservativos.

Infección por el virus Zika, prevención \& control; salud sexual; Estados Unidos. 
RESUMO Objetivo. Examinar o conhecimento sobre a transmissão do vírus zika e a percepção de risco de infecção e avaliar a variabilidade no uso de preservativos em uma amostra probabilística de adultos sexualmente ativos nos Estados Unidos.

Conhecimento e percepção de risco de zika em adultos sexualmente ativos nos Estados Unidos da América: resultados de uma amostra representativa nacional

Palavras-chave
Métodos. Os dados do estudo foram obtidos do ciclo de 2016 da Pesquisa Nacional de Saúde e Comportamento Sexual, uma amostra probabilística representativa nacional da população adulta dos Estados Unidos. A coleta foi realizada em novembro de 2016 em uma pesquisa transversal realizada pela internet administrada aos participantes de um painel de conhecimento, um serviço de amostragem aleatória por endereço gerido pela GfK. Uma submostra ponderada $(n=1.713)$, composta por adultos sexualmente ativos com idade de 18 a 50 anos, foi incluída nas análises.

Resultados. Acima de $90 \%$ dos homens e mulheres informaram percepção de baixo ou nenhum risco de infecção pelo vírus zika. A maioria dos participantes identificou a picada de mosquito como uma via de transmissão e uma proporção significativamente menor identificou a relação sexual $(\approx 40 \%)$ e a transmissão vertical ( $29 \%$ dos homens e $41 \%$ das mulheres) como vias de transmissão.

Conclusões. Falta conhecimento sobre a transmissão sexual e a transmissão vertical do vírus zika aos adultos sexualmente ativos nos Estados Unidos, sobretudo aos jovens do sexo masculino. Diante da provável endemicidade do vírus, a percepção de baixo risco é um grande desafio à prevenção. As mensagens para prevenção de zika devem abordar as vias de transmissão menos conhecidas, concentrando-se em instruir indivíduos do sexo masculino e promover o uso correto e consistente de preservativos.

Infecção pelo Zika virus, prevenção \& controle; saúde sexual; Estados Unidos. 